\title{
ANALISIS DAMPAK HARGA MINYAK MENTAH DUNIA, TINGKAT SUKU BUNGA DAN KURS VALUTA ASING TERHADAP INDEKS HARGA SAHAM PERTAMBANGAN PERIODE 2014 - 2016
}

\author{
Jessica P. S, \\ Universitas Katolik Indonesia Atma Jaya \\ Jessica_pau@gmail.com \\ Selly Eriska M \\ Sekolah Tinggi Ilmu Ekonomi JIU, Jakarta, \\ selly_riska@yahoo.com
}

\begin{abstract}
This study aims to look at the effect of world crude oil prices, interest rates, and foreign exchange rates on the mining sector stock price index for the 2014-2016 period. The research method used is descriptive statistical methods with quantitative research types. This study also uses analytical methods such as multiple regression analysis through $t$ test and F test. Based on the F test (simultaneous) shows that world oil prices, interest rates, and foreign exchange rates affect simultaneously on the mining sector stock price index for the period 2014-2016, while the t test (partial) shows that world crude oil prices a positive but not significant effect on the mining stock price index for the period 2014-2016, the interest rate has a negative effect and significant to the mining sector stock price index for the period 2014-2016, and the foreign exchange rate has a negative and significant effect on the price index mining sector shares in the 2014-2016 period.
\end{abstract}

Keywords: World Crude Oil Prices, Interest Rates, Foreign Exchange Rates, Indices Mining Sector Stock Prices

\section{PENDAHULUAN}

Pada awal Oktober 2016 indeks harga saham pertambangan mengalami kenaikan yang cukup signifikan yaitu sebesar 53,35\%. Angka ini bahkan mengalahkan kenaikan Indeks Harga Saham Gabungan (IHSG) yaitu sebesar $17,37 \%$ di periode yang sama. Kenaikan harga saham sektor pertambangan ini tidak terlepas dari harga minyak dunia yang mulai pulih di tahun 2016, dimana harga minyak mentah jenis WTI kembali diperdagangkan di harga $\$ 50,20$ per barel pada akhir atau naik lebih dari $91 \%$ dari level terendahnya \$26,21 per barel di bulan Februari 2016. Disisi lain, penurunan suku bunga yang berasal dari pengembangan kebijakan moneter menyebabkan obligasi menjadi 
kurang atraktif dibandingkan saham sehingga menyebabkan harga saham menjadi naik (Taufeeq Ajaz Md. Zulquar Nain Bandi Kamaiah Naresh Kumar Sharma, 2017:3). Jika dilihat pada kenyataannya, dengan adanya suku bunga yang tinggi, masyarakat akan cenderung bermain aman dengan menabung di bank daripada berinvestasi di pasar modal (beritasatu.com). Ketika suku bunga turun, maka menabung menjadi tidak menguntungkan sehingga masyarakat akan memilih berinvestasi di pasar modal baik obligasi maupun saham karena imbal hasil yang lebih besar (ekbis.sindonews.com Jumat 19 Februari 2016). Suku bunga ini juga dikaitkan dengan suku bunga The FED yang menjadi patokan para investor. Kurs mata uang juga mempengaruhi harga saham perrtambangan di Indonesia. Apabila kurs mata uang lokal mengalami depresiasi, maka ini akan mendorong kegiatan ekspor dan meningkatkan profit dari perusahaan. Adanya kenaikan profit ini akan menyebabkan kenaikan harga saham (Taufeeq Ajaz, Md. Zulquar Nain, Bandi Kamaiah Naresh, Kumar, 2017:2). Menguatnya mata uang asing juga dapat menimbulkan dampak yang buruk khususnya bagi negara yang banyak mengimpor barang dari luar negeri karena biaya yang dikeluarkan menjadi meningkat. Ada banyak faktor yang mempengaruhi harga saham pertambangan di Indonesia dimana salah satunya adalah harga minyak mentah dunia. Harga minyak mentah di dunia sekarang ini yang menjadi patokan ada dua yaitu Brent Crude Oil dan West Texas Intermediate (WTI) (Seputarforex, 11 September 2017). Brent Crude Oil merupakan patokan harga minyak mentah yang dipakai di Eropa sedangkan West Texas Intermediate Crude Oil merupakan patokan harga minyak mentah yang dipakai di Amerika Serikat. Perbedaan antara Brent Crude Oil dan West Texas Intermediate Crude Oil adalah pada harga penjualannya. Penjualan WTI Crude Oil tercatat lebih murah dibandingkan dengan Brent Crude Oil. Selain itu, karena Amerika Serikat juga menyumbang $36,3 \%$ dalam pergerakan pasar modal sehingga saat ini patokan harga minyak mentah menggunakan harga West Texas Intermediate Crude Oil. Dengan adanya faktor-faktor diatas, penulis ingin maka penulis melakukan penelitian pengaruh harga minyak mentah dunia, tingkat suku bunga, dan kurs valuta asing terhadap indeks harga 
saham pertambangan periode 20142016. Berdasarkan latar belakang penelitian, identifikasi masalah dalam penelitian ini adalah:

1. Melihat bahwa berfluktuasinya harga minyak mentah saat ini, maka penulis ingin mengetahui apakah harga minyak mentah dunia memiliki pengaruh yang signifikan terhadap indeks harga saham pertambangan.

2. Melihat bahwa tingkat suku bunga Indonesia yang mulai menurun, maka penulis ingin mengetahui apakah suku bunga memiliki pengaruh yang signifikan terhadap indeks harga saham pertambangan.

3. Melihat bahwa kurs valuta asing masih berfluktuasi, maka penulis ingin mengetahui apakah kurs valuta asing memiliki pengaruh yang signifikan terhadap indeks harga saham pertambangan

Mengingat luasnya ruang lingkup permasalahan dalam penelitian ini, maka penelitian hanya dibatasi pada:

1. Variabel independen yang dipakai dalam penelitian ini yaitu harga minyak dunia, suku bunga, dan kurs valuta asing.

2. Harga minyak dunia yang digunakan adalah West Texas Intermediate Crude Oil.

3. Penelitian hanya dilakukan pada indeks harga saham sektor pertambangan periode 20142016.

4. Suku bunga yang dipakai adalah BI Rate dan 7 Days-Repo Rate

Berdasarkan identifikasi masalah penelitian, maka perumusan masalah dalam penelitian ini adalah:

1. Apakah harga minyak mentah dunia memiliki pengaruh yang signifikan terhadap indeks harga saham pertambangan periode 2014- 2016?

2. Apakah tingkat suku bunga memiliki pengaruh yang signifikan terhadap indeks harga saham pertambangan periode 2014-2016?

3. Apakah kurs valuta asing memiliki pengaruh yang signifikan terhadap indeks harga saham pertambangan periode 2014-2016?

4. Apakah harga minyak mentah dunia, tingkat suku bunga, dan kurs valuta asing memiliki 
pengaruh yang signifikan secara simultan terhadap indeks harga saham pertambangan periode 2014-2016?

\section{Tujuan Penelitian}

Penelitian ini bertujuan:

1. Untuk mengetahui pengaruh harga minyak mentah dunia terhadap indeks harga saham pertambangan periode 20142016.

2. Untuk mengetahui pengaruh tingkat suku bunga terhadap indeks harga saham pertambangan periode 2014-

\section{TELAAH LITERATUR}

Investasi

Menurut Azis, et al (2015:234), investasi adalah sejumlah dana atau sumber daya lainnya yang dilakukan pada saat ini, dengan tujuan memperoleh sejumlah keuntungan di masa datang, sedangkan menurut Fransiskus (2016:11), investasi adalah sebuah aktivitas yang bertujuan untuk mendapatkan keuntungan di masa mendatang dengan memanfaatkan modal atau aset di masa sekarang. Investasi juga dapat diartikan sebagai penundaan konsumsi sekarang untuk
2016.

3. Untuk mengetahui pengaruh kurs valuta asing terhadap indeks harga saham pertambangan periode 20142016.

4. Untuk mengetahui apakah harga minyak mentah dunia, tingkat suku bunga, dan kurs valuta asing memiliki pengaruh yang signifikan secara simultan terhadap indeks harga saham pertambangan periode 20142016

dimasukkan ke aktiva produktif selama periode waktu yang ditentukan. (Jogiyanto, 2015:5)

Fungsi dan Peran Pasar Modal

Pasar modal mempunyai 2 fungsi yaitu ekonomi dan keuangan. Di dalam ekonomi, pasar modal menyediakan fasilitas untuk memindahkan dana dari lender ke borrower. Dengan menginvestasikan dananya, lender mengharapkan adanya imbalan atau return dari penyertaan dana tersebut. Sedangkan bagi borrower, adanya dana dari luar dapat digunakan untuk usaha 
pengembangan usahanya tanpa menunggu dana dari hasil operasi perusahaannya. Di dalam keuangan, dengan cara menyediakan dana yang diperlukan oleh borrower dan para lender tanpa harus terlibat langsung dalam kepemilikan aktiva riil. (Zulfikar, 2016:11)

Indeks Harga Saham

Menurut Tjiptono

mengatakan bahwa indeks harga saham adalah indikator yang menunjukkan pergerakan harga saham. Indeks berfungsi sebagai indikator tren pasar, artinya pergerakan indeks menggambarkan kondisi pasar pada suatu saat, apakah pasar sedang aktif atau lesu

\section{Harga Minyak Mentah Dunia}

Minyak mentah dunia menjadi salah satu hasil tambang yang menjadi faktor penggerak perekonomian dunia. Industri di seluruh dunia masih mengandalkan bahan bakar minyak yang merupakan produk olahan minyak mentah sebagai bahan baku faktor produksi karena hasil olahan minyak mentah merupakan sumber energi. Minyak mentah terutama diklasifikasikan dalam berbagai jenis kandungan sulfur dan kepadatan minyak. Standar ini ditetapkan oleh American Petroluem Institute (API). Menurut API, satuan yang disebut gravity menandakan tingkat kepadatan minyak bumi. Minyak dengan gravity lebih dari 40 derajat dianggap sebagai minyak ringan, sementara minyak dengan gravity kurang dari 20 derajat dianggap sebagai minyak berat. Minyak yang memiliki gravity antara 20-40 derajat dianggap sebagai minyak sedang (moderat).(www.amazine.co).

Ada 4 jenis minyak mentah yang menjadi standar harga minyak yaitu: (www.amazine.co)

\section{Brent Blend}

Nama ini berasal dari lokasi geografis tempat minyak ini diekstrak. Campuran minyak jenis ini terutama berasal dari sumur yang berlokasi di laut utara Eropa. Brent Blend dianggap sebagai minyak mentah manis dengan kandungan $0,37 \%$ sulfur dan kepadatan 38,06 derajat, dengan demikian minyak jenis ini dikategorikan sebagai minyak mentah ringan yang terutama digunakan untuk membuat 
bensin. Sebagian besar brent blend diperdagangkan di Amerika Serikat dan negara negara Mediterania.

2. West Texas Intermediate

Minyak jenis ini memiliki sulfur dan kepadatan rendah. Kandungan sulfur berkisar $0,24 \%$ dan gravity atau kepadatan 39,6 derajat. Minyak ini disebut sebagai minyak mentah manis dan ringan dan dianggap memiliki kualitas baik untuk diolah menjadi bensin. Penyulingan terutama dilakukan di daerah Teluk dan Amerika Serikat. Minyak ini disebut pula sebagai WTI dan sering dijadikan acuan harga minyak global.

\section{Russian Export Blend}

Minyak jenis ini menjadi acuan bagi minyak mentah Rusia dan memiliki kepadatan 32 derajat serta kandungan sulfur 1,2\%. Kandungan sulfur yang tinggi membuat Russian Export Blend digolongkan sebagai minyak asam serta memiliki kepadatan sedang (medium). Harga minyak jenis ini umumnya ditentukan dari dua lokasi utama pengiriman yaitu Italia dan Belanda.

\section{Dubai Crude}

Minyak yang dihasilkan memiliki kepadatan rendah dengan gravity 31 derajat dan kandungan sulfur 2\%. Dubai Crude dijadikan acuan harga bagi minyak yang diekspor di Asia. Saat ini harga acuan minyak mentah yang umum digunakan adalah West Texas Intermediate (WTI) atau light sweet dan Brent Crude Oil. Kedua jenis minyak ini merupakan minyak jenis ringan dan manis meskipun WTI Crude Oil lebih ringan dan manis dibandingkan Brent Crude Oil. (www.commodityhq.co).

Oleh karena itu, minyak jenis WTI ini diperdagangkan lebih mahal namun karena adanya krisis di Libya, sekarang WTI Crude Oil diperdagangkan lebih murah dibandingkan Brent Crude Oil dan juga produksi Brent Crude Oil semakin menurun sehingga peran WTI Crude Oil semakin meningkat. Selisih harga Brent dan WTI menyebabkan pembeli minyak internasional tertarik 
membeli WTI Crude Oil. ((http://investasi.kontan.co.id)

Tingkat Suku Bunga

Menurut Kasmir (2015:114) bunga bank dapat diartikan sebagai balas jasa yang diberikan oleh bank yang berdasarkan prinsip konvensional kepada nasabah yang membeli atau menjual produknya. Bunga juga dapat diartikan sebagai harga yang harus dibayar kepada nasabah (yang memiliki simpanan).

\section{BI Rate}

BI Rate adalah suku bunga kebijakan yang mencerminkan sikap atau stance kebijakann moneter yang ditetapkan oleh bank Indonesia dan diumumkan oleh publik (www.bi.go.id). BI Rate diumumkan oleh Dewan Gubernur Bank Indonesia setiap Rapat Dewan Gubernur bulanan dan diimplementasikan pada operasi moneter yang dilakukan Bank Indonesia melalui pengelolaan likuiditas di pasar uang untuk mencapau sasaran operasional kebijakan moneter. Sasaran operasional kebijakan moneter dicerminkan pada perkembangan suku bunga Pasar Uang Antar Bank Overnight (PUAB O/N). Pergerakan di suku bunga PUAB ini diharapkan akan diikuti oleh perkembangan di suku bunga deposito dan pada gilirannya suku bunga kredit perbankan. Bank Indonesia melakukan penguatan kerangka operasi moneter dengan memperkenalkan suku bunga acuan atau suku bunga kebijakan baru yaitu BI 7Days Repo Rate, yang akan berlaku efektif sejak 19 Agustus 2016.

\section{Kurs Valuta Asing}

Menurut Sukirno (2016:397) kurs valuta asing atau kurs mata uang asing menunjukkan harga atau nilai mata uang suatu negara dinyatakan dalam nilai mata uang negara lain. Kurs valuta asing dapat juga didefinisikan sebagai jumlah uang domestik yang dibutuhkan, yaitu banyaknya rupiah yang dibutuhkan untuk memperoleh satu unit mata uang asing

Hubungan antara Harga Minyak Mentah Dunia Terhadap Indeks Harga Saham Pertambangan.

Harga Minyak Mentah Dunia akan menjadi positif bagi negara-negara pengekspor minyak serta akan menjadi negatif untuk negara-negara yang mengimpor minyak dari luar negeri karena kenaikan harga minyak dunia 
akan menimbulkan kenaikan biaya yang juga akan menyebabkan kenaikan harga penjualan. Hal ini didukung oleh penjelasan Al-Fayoumi di dalam jurnal penelitian Tarak Nath Sahu, Kalpataru Bandopadhyay, dan Debasish Mondal (2013) yang mengatakan bahwa apabila perusahaan tidak bisa menyalurkan kenaikan biaya ke konsumennya, maka harga saham akan menurun. Hasil penelitian Tarak Nath Sahu, Kalpataru Bandopadhyay, dan Debasish Mondal (2013) menyimpulkan bahwa adanya hubungan jangka panjang yang positif antara harga minyak mentah dunia dan indeks harga saham.

Hubungan antara Tingkat Suku Bunga terhadap Indeks Harga Saham Pertambangan.

Hasil penelitian Taufeeq Ajaz Md. Zulquar Nain Bandi Kamaiah Naresh Kumar Sharma (2017) menyatakan bahwa tingkat suku bunga berpengaruh terhadap harga saham. Hal ini karena kebijakan uang ketat ini bisa menaikkan risiko saham dan mengurangi kemauan investor saham untuk menanggung risiko.

Hubungan antara Kurs Valuta Asing terhadap Indeks Harga Saham

Pertambangan

Hasil penelitian Taufeeq Ajaz (2017) menunjukkan bahwa kurs valuta asing berpengaruh positif dan signifikan terhadap harga saham untuk negara yang melakukan ekspor namun akan kurs valuta asing berpengaruh negatif dan signifikan terhadap harga saham bagi negara yang melakukan impor. Penelitian ini didukung oleh Franky (2015) yang menunjukkan bahwa kurs valuta asing berpengaruh negative dan signifikan terhadap indeks harga saham pertambangan. Kurs valuta asing menaikkan biaya impor. Hal ini menyebabkan kenaikan biaya produksi (Taufeeq Ajaz, 2017) 
Gambar 1 Paradigma Penelitian

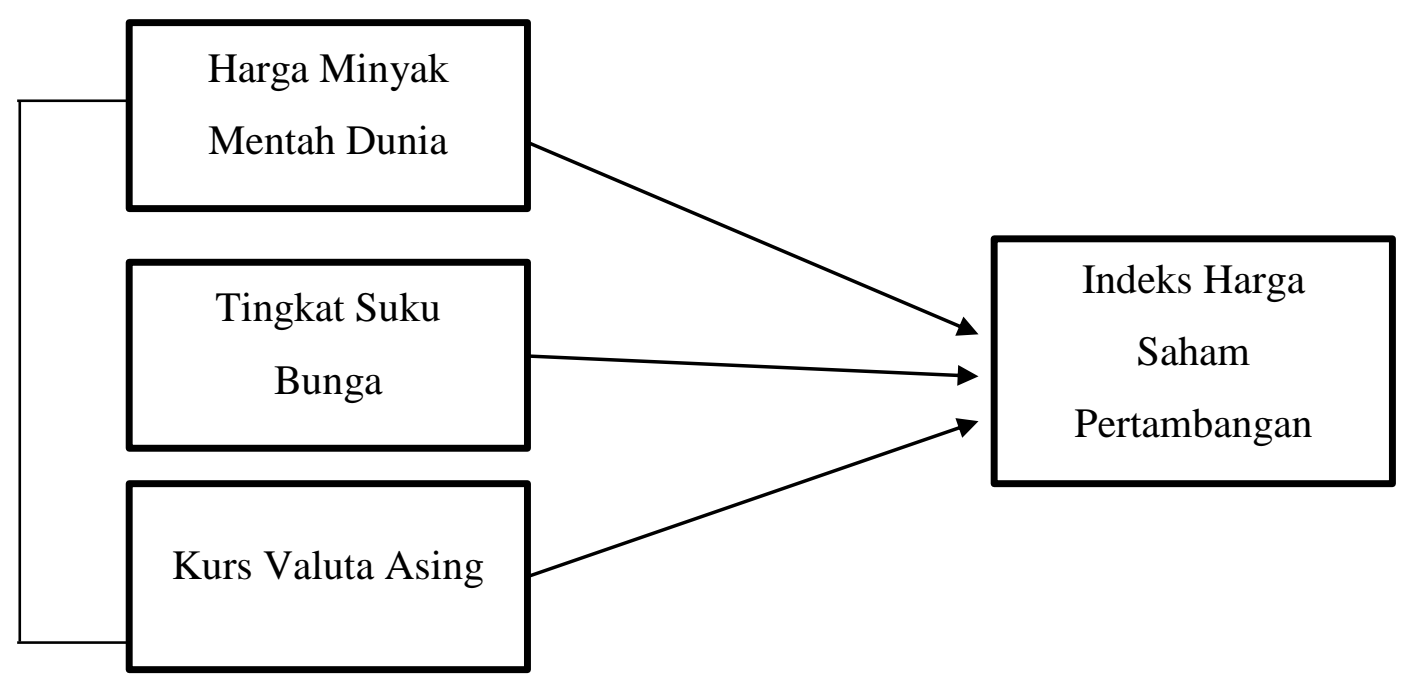

\section{METODE PENELITIAN}

Subjek penelitian yang digunakan dalam penelitian ini adalah indeks harga saham pertambangan Indonesia selama periode 2014 - 2016. Peneliti menggunakan perusahaan sektor pertambangan karena pada penelitian ini, sektor pertambangan yang paling dipengaruh dari dampak perubahan harga minyak mentah dunia. Selain itu, sektor ini lah yang menjadi primadona pada tahun 2016 dimana sektor pertambangan naik sebesar 53,35\% mengalahkan IHSG yang mengalami kenaikan 17,37\%. Objek penelitian dalam penelitian ini adalah pengaruh harga minyak mentah dunia, tingkat suku bunga, dan kurs valuta asing. Metode yang digunakan dalam penelitian ini adalah metode statistik deskriptif dengan jenis penelitian yang bersifat kuantitaf, yaitu hasil penelitian yang kemudian diolah dan dianalisis untuk diambil kesimpulannya, artinya penelitian yang dilakukan adalah penelitian yang menekankan analisisnya pada data-data numeric (angka). Jenis data yang digunakan dalam penelitian ini adalah data sekunder dengan menggunakan data bulanan yaitu data time series dari setiap variabel yang digunakan. Data sekunder yang digunakan dalam penelitian ini antara lain:

1. Data bulanan indeks harga saham penutupan (Closing Price) sektor pertambangan selama periode 2014 - 2016 yang dipublikasikan (http://finance.yahoo.com). 
2. Data bulanan harga minyak WTI (West Texas Intermediate) selama periode $2014-2016$ yang dipublikasikan di (http://id.investing.com).

3. Tingkat suku bunga bulanan selama periode 2014-2016 yang dipublikasikan di (http://bi.go.id).

4. Nilai Tukar Rupiah terhadap dolar selama periode 2014-2016 yang

5. Dipublikasikan di (http://kemendag.go.id).

Populasi dalam penelitian ini adalah indeks harga saham sektoral yang terdaftar di Bursa Efek Indonesia. Teknik pengambilan data yang digunakan dalam penelitian ini adalah non probability sampling dengan menggunakan sampling jenuh atau sampel total, yaitu teknik penentuan sampel dimana semua anggota populasi digunakan sebagai sampel (Sugiyono, 2015:67). Sampel dalam penelitian ini adalah indeks harga saham sektor pertambangan yang terdaftar di Bursa Efek Indonesia selama periode 2014 2016. Berdasarkan kriteria tersebut penelitian ini dilakukan dengan menggunakan jumlah sampel dengan menggunakan data time series (bulanan) selama 36 bulan pengamatan. Apabila dalam suatu penelitian sudah memenuhi dan lolos uji asumsi klasik, maka akan dilakukan uji statistik dengan menggunakan analisis regresi linier berganda. Analisis regresi linier berganda adalah analisis bila peneliti bermaksud meramalkan bagaimana keadaan (naik turunnya) variabel dependen (kriterium), bila dua atau lebih variabel independen sebagai faktor prediktor dimanipulasi (dinaik turunkan nilainya). (Sugiyono, 2015:275). Uji t digunakan untuk mengetahui variabel independen secara parsial (individu) terhadap variabel dependen, apakah mempunyai pengaruh signifikan atau tidak. Tingkat signifikansi yang digunakan adalah 5\%. Uji F digunakan untuk mengetahui pengaruh variabel independen secara bersama-sama terhadap variabel dependen, apakah mempunyai pengaruh yang signifikan atau tidak. Dasar pengambilan keputusan dalam uji $\mathrm{F}$ adalah dengan menggunakan tingkat signifikansi sebesar $5 \%$. 


\section{PEMBAHASAN}

Tabel 1 Hasil Analisis Regresi Berganda

\begin{tabular}{|c|c|c|c|c|c|}
\hline \multirow{2}{*}{ Model } & \multicolumn{2}{|c|}{$\begin{array}{l}\text { Unstandardized } \\
\text { Coefficients }\end{array}$} & \multirow[t]{2}{*}{$\begin{array}{l}\text { Standardized } \\
\text { Coefficients }\end{array}$} & \multirow[t]{2}{*}{$\mathbf{t}$} & \multirow{2}{*}{ Sig. } \\
\hline & B & $\begin{array}{l}\text { Std. } \\
\text { Error }\end{array}$ & & & \\
\hline (Constant) & 496.265 & 525.93 & & .944 & .353 \\
\hline $\begin{array}{l}\text { WTI Crude } \\
\text { Oil }\end{array}$ & 25.887 & 59.798 & .037 & .433 & .668 \\
\hline $\begin{array}{l}\text { Tingkat } \\
\text { Suku Bunga }\end{array}$ & -266.073 & 65.948 & -.165 & -4.035 & .000 \\
\hline $\begin{array}{l}\text { Kurs Valuta } \\
\text { Asing }\end{array}$ & -.077 & .023 & -.261 & -3.298 & .003 \\
\hline Lag_Y & .741 & .069 & .730 & 10.720 & .000 \\
\hline
\end{tabular}

Uji koefisien regresi harga minyak mentah dunia terhadap indeks harga saham sektor pertambangan periode 2014-2016

Uji koefisien regresi harga minyak mentah dunia terhadap indeks harga saham sektor pertambangan periode 2014-2016 Berdasarkan hasil pengujian koefisien regresi dimana nilai signifikansi sebesar $0,668<$ dari nilai $\alpha$ yaitu 0,05 dengan nilai $\beta$ sebesar 25,887 yang dapat disimpulkan bahwa harga minyak mentah dunia memiliki pengaruh positif namun tidak signifikan terhadap indeks harga saham sector pertambangan periode 2014-2016. Hal ini sesuai dengan penelitian Babatunde, et al (2013) yang menyimpulkan bahwa adanya respon positif antara goncangan harga minyak mentah terhadap harga saham tetapi tidak sesuai dengan penelitian Noel Pardede, et al (2016) yang mengatakan bahwa harga minyak mentah dunia berpengaruh signifikan terhadap indeks harga saham pertambangan di Indonesia. Hal ini dikarenakan Indonesia memiliki standarisasi harga minyak tersendiri yaitu Indonesian Crude Price (ICP). Selama ini harga ICP masih menggunakan formula $50 \%$ dari RIM Intellegence Co dan sisanya dari Platts. (www.katadata.co.id). Platts merupakan penyedia data harga energi dan informasi pasar energi global yang bermarkas di Singapura sementara RIM Intellegence Co adalah lembaga independen pasar minyak pertama di Jepang. Selama ini harga ICP berada di bawah harga Brent dan WTI. Kenaikan 
WTI Crude Oil tidak begitu berpengaruh terhadap ICP karena standarisasi ICP masih mengikuti harga RIM dan Platts. Selain itu, kenaikan harga minyak mentah dunia juga menyebabkan kenaikan harga batu bara. Meningkatnya harga batu bara dunia tercermin dari harga batu bara acuan yang meningkat menjadi $\$ 69,07$ per

Uji koefisien regresi tingkat suku bunga terhadap indeks harga saham sektor pertambangan periode 2014-2016.

Berdasarkan hasil pengujian koefisien regresi dimana nilai signifikansi sebesar $0,000<$ dari nilai $\alpha$ yaitu 0,05 dengan $\beta$ sebesar -266,073 yang dapat disimpulkan bahwa tingkat suku bunga memiliki pengaruh negative dan signifikan terhadap indeks harga saham sektor pertambangan periode 20142016. Hal ini sesuai dengan penelitian Taufeeq et al (2017) yang menyatakan bahwa tingkat suku bunga berpengaruh terhadap harga saham. Hal ini dikarenakan ketika suku bunga naik, masyarakat cenderung bermain aman dengan menabung di bank daripada berinvestasi di pasar modal (beritasatu.com). Begitu juga ketika suku bunga turun, maka menabung menjadi tidak menguntungkan sehingga metrik ton pada Oktober 2016. Hal ini didukung juga dengan kinerja pemerintah dalam menekan angka inflasi menjadi 3,02\% pada tahun 2016 dan program pemerintah dalam membangun listrik 19.000 MW yang sudah mulai berjalan. Perencanaan ini akan membutuhkan banyak batu bara.

masyarakat akan memilih berinvestasi di pasar modal baik obligasi maupun saham karena imbal hasil yang lebih besar (ekbis.sindonews.com). Suku bunga juga dikaitkan dengan suku bunga The FED. Apabila The FED ingin menaikkan suku bunga, rata-rata investor akan cenderung untuk tidak masuk ke pasar modal karena pasar investor asing ingin berencana untuk menarik dananya kembali dan bermain pada instrument investasi dengan mata uang Dolar karena lebih menguntungkan. Sekitar bulan Agustus 2016, Suku bunga acuan perbankan berubah menjadi BI-7 Days Repo Rate. Adanya perubahan suku bunga acuan ini, pemerintah berharap agar dapat lebih cepat mempengaruhi pasar uang, perbankan, dan sektor riil dan memiliki hubungan yang lebih kuat ke suku bunga pasar uang. 
Uji koefisien regresi kurs valuta asing terhadap indeks harga saham sektor pertambangan periode 2014-2016.

Berdasarkan hasil pengujian koefisien regresi dimana nilai signifikansi sebesar $0,003<$ dari nilai $\alpha$ yaitu 0,05 dengan nilai $\beta$ sebesar $-0,077$ yang dapat disimpulkan bahwa kurs valuta asing berpengaruh negatif dan signifikan terhadap indeks harga saham sektor pertambangan periode 2014-2016. Hal ini sesuai dengan penelitian Taufeeq et al (2017) yang menyatakan bahwa kurs valuta asing berpengaruh negatif dan signfikan terhadap negara yang melakukan impor. Penelitian ini juga didukung oleh Franky (2015) yang menyatakan bahwa kurs valuta asing berpengaruh negatif dan signifikan terhadap indeks harga saham pertambangan. Hal ini disebabkan karena negara Indonesia merupakan negara yang lebih banyak mengimpor minyak mentah daripada mengekspor minyak mentah. Melihat hal tersebut berarti Indonesia bergantung pada pertukaran mata uang dengan negara dimana Indonesia mengimpor minyak mentah. Apabila mata uang lokal (rupiah) mengalami penurunan (depresiasi), dengan kata lain mata uang asing mengalami peningkatan (apresiasi), maka akan menaikkan biaya impor sehingga menyebabkan kenaikan biaya produksi (Taufeeq et al 2017). Meningkatnya biaya impor, berarti perusahaan pengimpor minyak harus bisa menyalurkan biaya tersebut kepada konsumen dengan cara menaikkan harga

Tabel 2 Hasil Pengujian ANOVA ${ }^{b}$

\begin{tabular}{|c|c|c|c|c|c|c|}
\hline Model & & $\begin{array}{l}\text { Sum of } \\
\text { Squares }\end{array}$ & df & Mean Square & $\mathbf{F}$ & Sig. \\
\hline & Regression & 1965519.5 & 4 & 491379.874 & 167.559 & $.000^{a}$ \\
\hline & Residual & $\mathbf{8 7 9 7 7 . 5 5 2}$ & 30 & 2932.585 & & \\
\hline & Total & 2053497.05 & 34 & & & \\
\hline \multicolumn{7}{|c|}{$\begin{array}{l}\text { a. Predictors: (Constant), Indeks Harga Saham Pertambangan } \\
\text { b. Dependent Variable: Lag_Y, Tingkat Suku Bunga, Kurs } \\
\text { Valuta Asing. WTI Crude Oil }\end{array}$} \\
\hline
\end{tabular}


Uji koefisien regresi harga minyak mentah dunia, tingkat suku bunga, dan kurs valuta asing terhadap indeks harga saham sektor pertambangan periode 2014-2016 Berdasarkan hasil pengujian koefisien regresi dimana nilai signifikansi sebesar $0,000<$ dari nilai $\alpha$ yaitu 0,05 yang dapat disimpulkan bahwa ada pengaruh yang signifikan dari harga minyak mentah dunia, tingkat suku bunga, dan kurs valuta asing secara simultan terhadap indeks harga saham sektor pertambangan periode 2014-2016. Hal ini dikarenakan bahwa negara Indonesia merupakan negara pengimpor minyak mentah. Melihat fakta tersebut maka negara Indonesia harus berpatokan pada nilai tukar mata uang negara dimana Indonesia mengimpor minyak mentah. Apabila nilai mata uang asing mengalami apresiasi sedangkan nilai mata uang lokal mengalami depresiasi

\section{SIMPULAN DAN SARAN}

Berdasarkan analisis hasil penelitian dan pembahasan yang telah diteliti pada bab-bab sebelumnya, maka simpulan yang dapat diperoleh dari penelitian ini adalah sebagai berikut:

1. Harga minyak mentah secara disertai dengan kenaikan harga minyak mentah dunia, maka akan menyebabkan kenaikan biaya impor (Taufeeq, et al 2017). Kenaikan biaya impor ini akan menyebabkan kenaikan harga jual karena perusahaan harus menyalurkan kenaikan biaya tersebut dengan menaikkan harga. Kenaikan harga ini umumnya akan menyebabkan permintaan menurun. Melihat adanya kenaikan harga ini akan menyebabkan inflasi. Untuk mengatasi kenaikan inflasi ini, pemerintah akan menerapkan kebijakan uang ketat dengan cara menaikkan suku bunga. Kenaikan suku bunga ini akan menyebabkan masyarakat cenderung bermain aman dengan menabung di bank daripada berinvestasi di pasar modal sehingga menyebabkan harga saham menjadi menurun

individu memiliki pengaruh positif dan tidak signifikan terhadap indeks harga saham sektor pertambangan periode 2014-2016. Hal ini dikarenakan Indonesia memiliki standarisasi harga minyak sendiri yaitu 
Indonesian Crude Price (ICP).

Standarisasi ini masih mengikuti harga RIM dan

Platts serta standarisasi masih berada dibawah harga Brent dan WTI. Kenaikan harga minyak mentah dunia diikuti dengan meningkatnya harga batu bara. Kenaikan harga batu bara ini menjadi respon positif bagi emiten sektor pertambangan yang tergabung kedalam indeks harga saham sektor pertambangan karena program listrik pemerintah 19.000 MW yang membutuhkan banyak batu bara sehingga menjadi respon positif bagi emiten yang akan berimbas ke meningkatnya harga saham.

2. Tingkat suku bunga secara individu memiliki pengaruh negatif dan signifikan terhadap indeks harga saham sektor pertambangan periode 20142016. Hal ini terlihat dalam periode pengamatan, tren pergerakan tingkat suku bunga tidak searah dengan tren pergerakan indeks harga saham sektor pertambangan.
Tingginya tingkat suku bunga, menyebabkan pasar modal menjadi tidak menguntungkan karena akan lebih untung dan aman untuk menabung di bank daripada berinvestasi di pasar modal yang lebih berisiko.

3. Kurs valuta asing secara individu memiliki pengaruh negatif dan signifikan terhadap indeks harga saham sektor pertambangan periode 20142016. Hal ini terlihat dalam periode pengamatan, tren pergerakan kurs valuta asing bergerak tidak searah dengan tren pergerakan indeks harga saham sektor pertambangan. Apabila kurs valuta asing mengalami apresiasi (nilai mata uang lokal terdepresiasi), maka akan menyebabkan biaya yang dikeluarkan oleh perusahaan semakin tinggi. Apabila perusahaan tidak bisa menyalurkan biaya tersebut ke konsumen, maka akan menyebabkan penurunan pada harga saham.

4. Berdasarkan hasil uji F, menunjukkan bahwa semua variable independen yang 
terdiri dari harga minyak mentah dunia, tingkat suku bunga, dan kurs valuta asing secara bersama-sama memiliki pengaruh yang signifikan terhadap indeks harga saham sektor pertambangan periode 2014-2016.

Berdasarkan hasil penelitian yang didapatkan, adapun saran-saran yang dapat diberikan peneliti adalah, investor agar dapat memperhatikan faktor makro ekonomi tersebut karena sama-sama berpengaruh terhadap indeks harga sektor pertambangan. Selain itu, disarankan untuk para investor untuk

\section{DAFTAR PUSTAKA}

Ajaz, Taufeeq, et, al (2017), Stock

Prices, exchange rate, and interest rate: evidence beyond symmetry,

(http://www.emeraldinsight.com /doi/full/10.1108/JFEP-01-20160007)

Babatunde, Musibau Adetunji, Olayinka Adenikinju, \& Adeola F. Adenikinju (2012), Oil Price Shocks And Stock Market Behaviour In Nigeria (http://www.emeraldinsight.com /doi/full/10.1108/014435813112 83664)

Bhaskar Bagchi (2017), Volatility Spillovers Between Crude Oil Price And Stock Market: tetap memperhatikan tingkat suku bunga The Fed yang menjadi faktor eksternal yang akan mempengaruhi pasar modal Indonesia. Karena keterbatasan penelitian, maka disarankan juga kepada para investor untuk tetap memperhatikan kebijakan pemerintah serta hal-hal yang berkaitan langsung dengan perusahaan sektor pertambangan karena kebijakankebijakan yang diambil oleh perusahaan merupakan roda penggerak perusahaan dan dapat menjadi acuan dasar untuk para investor dalam mengambil tindakan investasi.

Evidence From BRIC Counties, (http://www.emeraldinsight.com /doi/full/10.1108/IJoEM-042015-0077 diakses pada 9 Mei 2017)

Gujarati, D.N (2012), Dasar-Dasar Ekonometrika, Buku 2 Edisi 5. Salemba Empat, Jakarta.

Kasmir (2015), Bank dan Lembaga Keuangan Lainnya, Ed. Revisi, Cet. 16. Rajawali Pers, Jakarta. 
Pardede, Noel, et, al (2016), Pengaruh Harga Minyak Mentah Dunia, Inflasi, Suku Bunga (Central Bank Rate), Dan Nilai Tukar (Kurs) Terhadap Indeks Harga Saham Sektor Pertambangan Di ASEAN (Studi Pada Indonesia, Singapura, dan Thailand Periode Juli 2013 - Desember 2015),

Pardede, Ratlan \& Renhard Manurung (2014), Analisis Jalur, Rineka Cipta, Jakarta.

Sukirno, Sadono (2016),

Makroekonomi Teori Pengantar, Ed. 3, Cet. 24. Rajawali Pers, Jakarta.

Wathen, Lind Marchal (2012), TeknikTeknik Statistika Dalam Bisnis Dan Ekonomi Menggunakan Kelompok Data Global, Buku 2 Ed. 13. Salemba Empat, Jakarta.

http://administrasibisnis.studentjournal. ub.ac.id/index.php/jab/article/vie wfile/15 43/1926, diakses pada hari senin 8 Mei 2017

http://bisnis.liputan6.com/read/2295332 /ini-6-penyebab-turunnya-hargaminyak diakses pada hari Rabu, 15 November 2017.

http://commodityhq.com/education/crud e-oil-guide-brent-vs-wti-whats thedifference/,diakses pada hari Senin 4 September 2017. baruharga-minyak, diakses pada hari Rabu $21 \quad$ Maret 2018. 